\title{
Recognition of Structural Obstacles of Technologic Entrepreneurship in Science \& Technology Parks
}

\author{
Peyman Pournasr Khakbaz ${ }^{1}$, ${ }^{*}$ Mehdi Salimi Torkamani² \\ Islamic Azad University, Science and Research Branch, Tehran, Iran ${ }^{1}$ \\ University of Tehran, Tehran, Iran² \\ *m_salimi@ent.ut.ac.ir
}

\begin{abstract}
Nowadays, a large ratio of nation's educated population suffers from unemployment problem. Since the available capacity of employment in governmental jobs is limited, hence the entrepreneurship can be a solution for resolving this problem or at least reducing it. The entrepreneurship centers in universities can play an important role in developing and promoting the entrepreneurship. The aim of current research is to investigate the structural obstacles of technologic entrepreneurship in Tehran University's science \& technology Park. The research methodology is descriptive \& survey and is of applied type. The research statistical society is the technological entrepreneurs of Tehran University's science \& technology centers. Data gathering was carried out using researcher's questionnaire with a stability of $\alpha=0.92$. Data analysis was performed in two descriptive and inferential levels using software SPSS 16. The research results revealed that the entrance of unskilled individuals into technologic topics, the lack of skilled labor force required by technologic entrepreneurship and the lack of sufficient infrastructures for technologic businesses are among the structural obstacles of technologic entrepreneurship. The obtained results are in line with researches of Phan and Der-Foo (2004). Regarding the obtained results, one can promote the technological entrepreneurship through planning and adoption of applied strategies for resolving the recognized obstacles.
\end{abstract}

\section{Key words: Structural obstacles, technologic entrepreneurship, science \& technology Park}

\section{Introduction}

The 1960's decade is counted as an era full of ups and downs in the field of commercialization of technology in USA. The Federal's extensive investments in development of technology transfer, increase of demands for correction of technology transfer programs and more accountability in technology commercialization and in the same time, industry dissatisfaction were among the characteristics of this era (Motohashi, 2005). The entrepreneurships believe that in order to commercialize the technology, they require knowing its processes (or in other words, entrepreneur-oriented), hence this leads entrepreneurs to what they need to know and apply in variable and complex conditions (focus on business labor force) (Lindholm and Dahlstrand, 2007). Technologic entrepreneurship has been paid attentions in many countries as one of the effective factors in social, economical and even international domains and hence, it can institutionalize and promote a policy like entrepreneurship and creating employment through it, provided that the ahead obstacles and problems to be solved in order to be succeed as strong means for reaching economical and social development. However, the technologic entrepreneurship for small and middle-sized companies, in order to reach competitive advantage, needs to focus on organizational topics, develop the technological entrepreneurship and also needs innovation (Ratinho and Henriques, 2010). Hence, the necessity requires that regarding technological entrepreneurship, the supplemental solution to be employed along with massive programs that among them one can mention the research and study about the obstacles of business creation and technological entrepreneurship in science \& technology Parks. Hence, the main question of this research is that which are the structural obstacles of technologic entrepreneurship in science \& technology Parks?

\section{Literature review}

In general, there are considerable literatures about the term "technologic entrepreneurship". In a section of Burgleman et al (1996), the technologic entrepreneurship is considered as combination of commercialization and technology and it is treated as the foundation of technological innovation process. Also a comparison between traditional and technological entrepreneurship was performed. The traditional entrepreneur is a person who has the ability of opportunity recognition and commercial use of the new product or service, while the technological entrepreneur is one who has the ability of market 
recognition for employed technology that this finally results in technological innovations and new product development. Prodan (2009) has collected important concepts with regard to "technological entrepreneurship" and includes three main subjects as follows:

- The effect of environmental conditions on technological entrepreneurship

- The process which based on it, the entrepreneurs combine the organizational resource with technical systems

- The strategies which are adopted by entrepreneur firms in long time for application of opportunities

The environmental context is related to environmental factors in creation of new companies. The relationship between fundamental change and entrepreneurship opportunities in creation of entrepreneurial opportunities seems to be important. The "environmental shock" was introduced by Myer in 1982, "sudden variations which are hard to forecast and have often destructive effects on organizations". Then, this viewpoint was discussed by Shane and Venkataraman in 2003 in order to perform some investigations about revising the current institutional structures and to generate entrepreneurship opportunities. In other field, Rothaermel and Thursby (2005) suggested that the technological entrepreneurship should include firm as one of the other numerous players beside the entrepreneur and this firm should deeply be involved in the nature of the technological system it has created. Therefore, in summary, one can say that the technological entrepreneurship has various active aspects:

- Firstly, this concept is not only about discovery or invention, but also gains meaning with regard to creation at the same amount;

- Secondly, these players are involved in all inputs which are entered via technologic trend;

- Thirdly, the special processes for contribution of these players will be different depending on technology route.

Shane and Vankaterman (2003) considered three differences between traditional and technological entrepreneurship. First, the traditional literature about entrepreneurship has more focus on the entrepreneur's role in constructing the company processes, while, in the technological entrepreneurship the focus is not only on the entrepreneur's capabilities, but is also on various factors such as the role of technology, technical systems and the institutes. Secondly, the focus of entrepreneurship traditional literature is on the entrepreneur's minor attributes. In this literature, the entrepreneur is introduced as a person who doesn't work based on prediction of future environment and conditions. Technological Entrepreneur is one who takes responsibility for various activities: pre-detection of technological opportunities, gathering of resource and go ahead to reach the targets through regular and reasonable pattern. This process takes place gradually and wisely (Astebro, 2004). The third difference is that the traditional entrepreneurship literature doesn't have very relationships with other scientific fields, while a wide range of sciences interfere in the technological entrepreneurship literature such as technology management, risk management and ambiguity reduction, knowledge flow management and technological systems development (Shane and Venkataraman, 2003). The "international journal of technological innovation, entrepreneurship and technology management" has combined some areas of sciences such as technological innovations, entrepreneurship and technology management and has created a study field known as "technological entrepreneurship". Hence, the technological entrepreneurship is a concept which results in creation of business or emersion of new technology-based firms (NTBF) (Spencer and Kirchhof, 2006).

Souitaris (1998) after conducting a research named "entrepreneurs, organizations and sports markets" suggests that entrepreneurship provide the sports with a special and unique route and the future researches should investigate the sports from the standpoint of entrepreneurship. The international labour organization (ILO) counted some infrastructure obstacles like access to credits, supportive services, information and technology as the obstacles of women's entrepreneurship. Sui et al (2005) have investigated 250 hi-tech companies and mentioned the managerial problems as one of three major reasons for their failure. Wright et al (2006) in an investigation counted the most important managerial challenges ahead of sports businesses as follows: the lack of using the resources and facilities, economic problems, political environment, the lack of competent managers, executive conflict and conservative policies. Xiao (2008), in a research about Canadian sports investigated the opportunities and obstacles of sports, amusement and leisure institutions. Some of opportunities were counted as follows: technology expansion, development of small sports businesses, decrease of governmental incumbency in sports section, increase of Canadian education in higher educations, tendency to doing public sports, being 
amused and acquiring new experiences. Some of obstacles of entrepreneurship in Canadian sports were counted as follows: development of large organizations, lack of knowledge and experience for young entrepreneurs, decrease of governmental support for small institutions, instability in economics, lack of money and distribution of investments. Hayton (2005) in a research named "the relationship between economical freedom and entrepreneurship growth" concluded that government interference inhibits the entrepreneurial discovery process and prevents from those consequences which results in welfare. Freeman and Perez (1986) investigated the role of inevitable and opportunist entrepreneurship in economic development and concluded that the developing countries require to reinforce the conditions for development of infrastructures, performance of financial market and management skills.

\section{Methodology}

Since the aim of applied researches is to develop the applied science in a certain field, the current research is of applied type in terms of research aim and is of descriptive-analytic type in terms of the way of data gathering and since it looks for obtaining information about viewpoints of individuals, its nature is descriptive and is of survey type which has been carried out as field researches. The statistical society is the managers and entrepreneurs in Tehran University's science \& technology Park. Sampling was performed as full-count in managerial section including all managers and deputies of science \& technology Park. In the technologic entrepreneurs section, the purposive cluster sampling was employed with regard to sample limitations. In this research, the technological entrepreneurs are the persons who are active more than 3 years in the field of modern and knowledge-based technologies or have contributed in formation of newly established technology-based firms. The sample size in the first section (managers and deputies) was 35 persons and was collected in section 12 of the questionnaire and totally 47 questionnaires were collected. In order to gather the data and information related to variables of this research, the researcher's questionnaire was used. After interviewing with some of entrepreneurs and using data obtained from domestic and foreign researches, some questions were designed which were of closed type. In order to evaluate the validity of questionnaire, the content validity method was used which was verified after presenting to experts and elites of entrepreneurship. The stability of questionnaire was also estimated using the Cronbach's alpha coefficient $\alpha=0 / 92$. In this research, the findings were analyzed in two descriptive and inferential sections. In descriptive section, the frequency distribution tables and in inferential statistics section, the Friedman test, binomial distribution and Kolmogorov-Smirnov test were used. Regarding the research's special purposes, all operations were done using software SPSS 16.

\section{Results}

As shown in table $1,53 \%$ of respondents are in age range of 31 to 40 years and $17 \%$ of them are younger than 30 and $28 \%$ of them are between 41 and 50 years and the rest $0.2 \%$ are placed in the age range of 51-60 years. No subject was placed in the age range of above 60 years.

Table 1: Distribution of respondents in terms of age

\begin{tabular}{llll}
\hline Row & Number & Age Groups & Percentage \\
\hline 1 & 8 & Below 30 & 0.17 \\
2 & 25 & $31-40$ & 0.53 \\
3 & 13 & $41-50$ & 0.28 \\
4 & 1 & $51-60$ & 0.02 \\
5 & 0 & Above 60 & 0.00 \\
\hline
\end{tabular}

Regarding table $2,74 \%$ of all subjects are men and the women form $26 \%$ of respondents.

Table 2: Distribution of respondents in terms of gender

\begin{tabular}{llll}
\hline Row & Gender & Number & Percentage \\
\hline & feminine & 12 & 0.26 \\
& masculine & 35 & 0.74 \\
\hline
\end{tabular}

According to table 3, 26, 51 and $23 \%$ of respondents have Bachelor, Master and $\mathrm{PhD}$ degrees, respectively. 
Table 3: Distribution of respondents in terms of educational situation

\begin{tabular}{llll}
\hline Row & Number & Educational situation & percentage \\
\hline 1 & 12 & Bachelor & 0.26 \\
2 & 24 & Master & 0.51 \\
3 & 11 & PhD & 0.23 \\
\hline
\end{tabular}

As shown in table 4, distribution of research variables hasn't considerable difference with normal distribution and is actually normal.

Table 4: Descriptive indexes for evaluation of structural obstacle of technological entrepreneurship development from the standpoint of subjects

\begin{tabular}{|c|c|c|c|c|c|c|}
\hline $\begin{array}{l}\text { The obstacle for } \\
\text { entrepreneurship }\end{array}$ & $\begin{array}{l}\text { maximu } \\
\text { m }\end{array}$ & minimum & $\begin{array}{l}\text { Standard } \\
\text { deviation }\end{array}$ & average & $\begin{array}{l}\text { The test } \\
\text { distribution }\end{array}$ & or normal \\
\hline development & & & & & sig & $\begin{array}{l}\text { Kolmogoro } \\
\text { v-Smirnov }\end{array}$ \\
\hline structural & 2.44 & 4.78 & 0.50782 & 3.7969 & 0.452 & 0.859 \\
\hline
\end{tabular}

As one can see in table 5, the structural obstacles are existent in development of technological entrepreneurship in Tehran University's science \& technology Park.

Table 5: Results of binomial distribution test about existence or non-existence of structural obstacle in development of technological entrepreneurship in Tehran University's science \& technology Park

\begin{tabular}{lllllll}
\hline $\begin{array}{l}\text { index } \\
\text { variable }\end{array}$ & & $\begin{array}{l}\text { Significanc } \\
\text { e level }\end{array}$ & $\begin{array}{l}\text { Recorded } \\
\text { ratio }\end{array}$ & $\begin{array}{l}\text { Observed } \\
\text { ratio }\end{array}$ & number & groups \\
\hline structural & $\begin{array}{l}\text { Obstacle for } \\
\text { entrepreneurshi } \\
\text { p development }\end{array}$ & 0.000 & 50 & 0.90 & 81 & $\begin{array}{l}\text { significant } \\
\text { insignificant }\end{array}$ \\
& & & 0.10 & 9 & \\
\hline
\end{tabular}

\section{Discussion and Conclusion}

In investigation of structural obstacles for entrepreneurship development, the entrance of unskilled persons and the lack of technological entrepreneurs were counted among the most important factors, because one of the factors of success and superiority of organizations in $21^{\text {st }}$ century is the expert human resource (Grimaldi and Grandi, 2005). As emerged from the results of this research, the structural obstacles like the lack of knowledge and experience for entrepreneurs and consequently the lack of expert entrepreneurship human resource are among the obstacles of development of technological entrepreneurship which has an agreement with the results of Kalis (2001) and Hine and Kapeleris (2007). Among other obstacles in development of technological entrepreneurship, one can mention the lack of commercial, professional and occupational infrastructures. The lack of support of social and cultural norms with respect to entrepreneurship and the lack and insufficiency of governmental programs in giving help to new firms and also the interference of government in market are also among the mentioned obstacles which have caused that the business environment in Iran to be generally unfavorable and it is in accordance with the researches of Lindholm and Dahlstrand (2007), NGA (2004), Kalis (2001) and Scillitoe and Chakrabarti (2010). Lack of attention and resistance of public sector managers and employees to technological entrepreneurship is also among the obstacles of technological entrepreneurship which has agreement with the results of Siegel et al (2007) because the way of business management generates the entrepreneurship level and the skill in the activities and business and every day, the importance and capability of management is increased in the world. In fact, the managers style, as the most important organizational factor with 4 major roles, i.e. manufacturing, managerial, integrative and entrepreneurial roles, is among the most important factors which affect the entrepreneurship and the programming and paying attention to it can give rise to entrepreneurship development and formation of business environment. If managers ignore this issue, they would make little decisions with regard to entrepreneurship strategy. Most of developed countries are in transition state from the administrative or bureaucrat state to entrepreneurship state which this issue depends on those managers which not only doesn't resist against this issue, but also act as supporter and encourager. 
Table 6: The conditions of structural obstacles of entrepreneurship development for all subjects

\begin{tabular}{|c|c|c|c|c|c|c|}
\hline Row & Questions & $\begin{array}{l}\text { Very } \\
\text { low }\end{array}$ & low & Medium & high & $\begin{array}{l}\text { Very } \\
\text { high }\end{array}$ \\
\hline 1 & $\begin{array}{l}\text { Lack of entrepreneurship training programs in } \\
\text { scientific centers and business consultation services } \\
\text { in the field of technology }\end{array}$ & 1.65 & 2.48 & 22.31 & 50.41 & 23.14 \\
\hline 2 & $\begin{array}{l}\text { Lack of sufficient recognition about the way of } \\
\text { entrance to the market and developing the presence }\end{array}$ & 2.48 & 3.30 & 24.79 & 48.67 & 20.66 \\
\hline 3 & Government interference in market & 2.48 & 6.61 & 34.71 & 23.79 & 2.23 \\
\hline 4 & $\begin{array}{l}\text { Personalized and irregular allocation of credits by } \\
\text { banks }\end{array}$ & 1.65 & 8.26 & 23.14 & 28.92 & 38.10 \\
\hline 5 & $\begin{array}{l}\text { Inadequate and unclear conditions of supportive } \\
\text { laws about private ownership in the country in order } \\
\text { to facilitate the new investments }\end{array}$ & 83.0 & 3.30 & 24.79 & 38.82 & 32.31 \\
\hline 6 & $\begin{array}{l}\text { Lack of sufficient and basic infrastructures for } \\
\text { business (communications, transportations, banking } \\
\text { services, insurance, etc.) }\end{array}$ & 83.0 & 5.78 & 13.22 & 42.79 & 37.19 \\
\hline 7 & $\begin{array}{l}\text { Incorrect attitude of private sector about public } \\
\text { sector and unreasonable expectations with regard to } \\
\text { government }\end{array}$ & 5.78 & 9.91 & 38.01 & 23.97 & 22.31 \\
\hline 8 & $\begin{array}{l}\text { Unclear conditions about policies and supports of } \\
\text { government with respect to private sector and } \\
\text { technological entrepreneurs }\end{array}$ & 0.83 & 5.78 & 22.31 & 37.19 & 33.88 \\
\hline 9 & Entrance of unskilled persons & - & 6.61 & 8.2 & 19.83 & 65.30 \\
\hline 10 & $\begin{array}{l}\text { Existence of governmental though in non- } \\
\text { governmental public institutions }\end{array}$ & 3.30 & 2.48 & 33.88 & 36.36 & 23.97 \\
\hline 11 & $\begin{array}{l}\text { Lack of attention and resistance of private sector's } \\
\text { managers and employees to technological } \\
\text { entrepreneurship }\end{array}$ & 0.83 & 7.44 & 24.79 & 28.92 & 38.01 \\
\hline 12 & $\begin{array}{l}\text { Lack of entrepreneurship experts in the technology } \\
\text { section }\end{array}$ & - & 6.61 & 11.57 & 41.32 & 40.50 \\
\hline 13 & Lack of necessary incentives for entrepreneurship & 0.83 & 6.61 & & 0 & 34.71 \\
\hline 14 & $\begin{array}{l}\text { Lack of sufficient laws in the nation for management } \\
\text { of private sector }\end{array}$ & 1.65 & 3.30 & 23.97 & 37.19 & 33.90 \\
\hline 15 & $\begin{array}{l}\text { Multiplicity of decision making and supervising } \\
\text { authorities in entrepreneurship and business } \\
\text { formation }\end{array}$ & 0.83 & 9.91 & 25.62 & 39.67 & 23.97 \\
\hline 16 & $\begin{array}{l}\text { Inconsistency between the administrations and } \\
\text { organizations related to business formation }\end{array}$ & - & 6.61 & 23.14 & 35.53 & 24.71 \\
\hline 17 & $\begin{array}{l}\text { Inefficiency of entrepreneurship centers in } \\
\text { universities }\end{array}$ & 3.30 & 4.13 & 31.40 & 33.88 & 27.27 \\
\hline
\end{tabular}

Suggestions: Regarding the mentioned obstacles, attracting the attentions of government, managers and authorities of science \& technology centers to creation of strategies and practical programs for reduction and elimination of the obstacles is necessary and requires paying special attention to this domain. Hence, regarding the mission of entrepreneurship, the strategies and priorities such as entrepreneurship training in educational levels and resolving the obstacles of entrepreneurial activities for hi-tech technologies should be considered. Finally, regarding the importance of technology and knowledge-based firms in employment and also its role in development of the society, it is suggested that more investigations concerning the obstacles of technological entrepreneurship in growth centers and universities and science \& technology Parks be conducted and it is suggested to the authorities to present suitable facilities such as banking services, insurance and business infrastructures and to train expert human resources in this field and to employ the technology experts and managers in nation's modern technologies in order to increase the entrepreneurial activities and employment rate and hence bring about the means of development of technological entrepreneurship. 


\section{References}

Astebro, T. (2004). Key Success Factors for Technological Entrepreneurs' R\&D Projects. IEEE Transactions on Engineering Management, 51(3), 314-321.

Burgelman, R. A., Maidique, M. A., and Wheelright, S. C. (1996). Strategic Management of Technology and Innovation, Times Mirror Higher Education Group, Chicago.

Freeman, C. \& Perez, C. (1986). The Diffusion of Technical Innovation and Changes of Techno economic Paradigm. Paper presented at Venice Conference on Innovation Diffusion, March 17-21, 1986.

Grimaldi, R. \& Grandi A. (2005). Business incubators and new venture creation: An assessment of incubating models. Technovation, 25(2), 111-116.

Hayton, J. C. (2005). Competing in the new economy: the effect of intellectual capital on corporate entrepreneurship in high-technology new ventures. R\&D Management, 35(2), 37-55.

Hine, D. \& Kapeleris, J. (2007). Innovation and Entrepreneurship in Biotechnology, An international perspective: Concepts, Theories and Cases, 218-222.

Kalis, L. (2001). Technology Commercialization through New Company Formation, National Business Incubation Association (NBIA) Publications, Athens, OH (2001)

Lindholm, A. \& Dahlstrand, S. (2007). Technology-based entrepreneurship and regional development: the case of Sweden. European Business Review, 19(5), 375-386.

Motohashi, K. (2005). University-industry collaborations in Japan: The role of new technology based firms in transforming the National Innovation System. Research Policy, 34(5), 583-594.

Murray, R. M. \& Wilemon, D. (2007). The Strategy of Managing Innovation and Technology, 5-13.

NGA. (2004). A Governor's Guide to Building State Science and Technology Capacity, the National Governors Association.

Phan, P. H. \& Der-Foo, M. (2004). Technological entrepreneurship in emerging regions. Journal of business venturing, 19(1), 1-5.

Prodan, I. (2009). A model of technological Entrepreneurship, Handbook of Research on TechnoEntrepreneurship, 26-38.

Ratinho, T. \& Henriques, E. (2010). The role of science parks and business incubators in converging countries: Evidence from Portugal. Technovation, 30, 278-290.

Rothaermel, F. T. \& Thursby, M. (2005). Incubator firm failure or graduation? The role of university linkages. Research Policy, 34, 1076-1090.

Scillitoe, J. L. \& Chakrabarti, A. K. (2010). The role of incubator interactions in assisting new ventures. Technovation, 30(4), 155-167.

Shane, S. \& Venkataraman, S. (2003). Guest editors Introduction to the Special Issue on Technology Entrepreneurship. Research Policy, 32 (2), 181-184.

Siegel, S. D., Wright, Mike. \& Lokett, A. (2007). The rise of entrepreneurial activity at universities: organizational and societal implication. Industrial and corporate change, 16(4), 489-504.

Souitaris, V. (1998). Determinants of Technological Innovation in the Greek manufacturing industry, PhD Thesis, University of Bradford.

Spencer, A. S. \& Kirchhof, B. A. (2006). Schumpeter and new technology based firms: Towards a framework for how NTBFs cause creative destruction. International Entrepreneurship and Management Journal, 2(2), 145-156.

Sui, G. J., Sheng, M. H. \& Song, J. B. (2005). Study on high-tech industrialization based on regional difference of patenting. Management World, 8, 87-93.

Wright, M., Clarysse, B., Lockett, A. \& Binks, M. (2006). University spin-out companies and venture capital. Research Policy, 35(4), 481-501.

Xiao, W. (2008). Determinants of New Technology-based Firms Performance in Catch-Up Regions: Evidence from the U.S. Biopharmaceutical and IT Service Industries 1996-2005 Georgia Institute of Technology Dissertations 